Acta vet. scand. $1968,9,1-9$.

From the Department of Microbiology and Immunology, Veterinary College of Norway, Oslo.

\title{
SEROLOGICAL STUDIES ON PROTEINASES PRODUCED BY AEROMONAS SALMONICIDA AND OTHER AEROMONADS
}

\author{
By \\ Olav Sandvik and Olav Hagen
}

In the 7th edition of Bergey's Manual of Determinative Bacteriology (1957) the genus Aeromonas is devided into the 4 species Ae. liquefaciens, Ae. punctata, Ae. hydrophila and Ae. salmonicida on the basis of natural sources, together with physiological properties and pathogenicity. However, Eddy (1960) considered the last 3 names to be synonyms, whereas Schubert (1967) found biochemical basis for retaining the species Ae. punctata and Ae. hydrophila in addition to Ae. salmonicida. A number of additional species, probably identical with or closely related to the said species, have also been reported (Bergey's Manual). Further, in $1964 \mathrm{Merkel}$ et al. described an organism as a new Aeromonas species and proposed the name Ae. proteolytica.

Serological differentiation of different Aeromonas strains has a.o. been carried out by Caselitz \& Krebs (1961) by means of agglutination, precipitation, and complement fixation tests with cellular antigens. These workers concluded that serological differentiation within this genus is possible to some extent. The agglutination test was considered of limited value due to problems with spontaneous agglutination, whereas a precipitation procedure seemed to be more promising. Karlson (1964) compared 12 strains of Ae. salmonicida by agglutination and precipitation tests without observing any serological differences. On the other hand, these strains were serologically different from a human Aeromonas strain which was included for comparison.

Caselitz \& Günther (1960) studied strains of Aeromonas by means of antiserums prepared against their hemolysins. Different 
degrees of antigenic relationship could be demonstrated between hemolysins of the various strains.

Liu (1962) identified the so-called Pseudomonas caviae as Aeromonas liquefaciens by agar-gel precipitation with extracellular antigens against a specific antiserum. He also included neutralization of proteolytic activity by means of specific antiproteases in the identification of this organism. Sandvik (1962) described an immuno-electrophoretic method for serological differentiation of extracellular bacterial proteinases. By this method specific anti-proteinases were by paper electrophoresis separated from the normal, interfering proteinase inhibitors in serums of immunized rabbits. The anti-proteolytic effect of the specific anti-enzymes was then demonstrated by their ability to inhibit the corresponding enzymes from precipitating sodium caseinate in an agar medium. Many serologically different proteolytic enzymes were demonstrated in a material of various species. Most of the enzymes were specific for species, and cross-reactions between species and genera were exceptional. Serological identification of extracellular bacterial enzymes and other extracellular antigens is considered a valuable taxonomic criterion ( Liu; Sand$v i k)$. By using proteinases or other antigens that are labelled by their functional, enzymatic properties, it is possible to identify the corresponding organisms without purifying the enzymes.

The authors have used this immuno-electrophoretic method in comparing Aeromonas strains originating from fresh-water fish and other sources. The aim of the present work has been to search for reliable and convenient criteria in the identification of Ae. salmonicida and to study the possible serological relationship between different species of the genus Aeromonas.

\section{MATERIALS AND METHODS}

Strains. Of a total of 12 Aeromonas strains used in this study (Table 1), 6 - in the following designated as Danish strains - were obtained from Dr. M. H. Jensen, State Veterinary Serum Laboratory, Department of Jutland, Aarhus, Denmark. These strains were isolated from cases of furunculosis in rainbow trouts and identified as Aeromonas salmonicida. Six strains were obtained from the American Type Culture Collection (ATCG), Rockville, Maryland, USA, and 1 strain $\left(\mathrm{NVH}^{*}\right)$ 2568) was isolated from a case of furunculosis in rainbow

*) $\mathrm{NVH}=$ The Culture Collection at the Department of Microbiology and Immunology, Veterinary College of Norway. 
trout by the authors. All the strains corresponded mainly with the respective cultural, morphological and biochemical properties listed in Bergey's Manual (1957). The strains of Ae. salmonicida included all produced brown pigment in Bacto-Furunculosis Agar (Difco). This was, however, also the case with Ae. liquefaciens (ATCC 14715).

One strain of each the following Gram-negative organisms was included for comparison: Pseudomonas aeruginosa (NVH 150), Pseudomonas fluorescens (NVH 1859), Proteus vulgaris (NVH 418) and Aerobacter cloacae $\left(\right.$ NCIB $\left.\left.^{\star}\right) 5920\right)$.

Enzymes. The various proteinases were produced by growing the organisms on semi-solid skim milk agar (nutrient broth, $40 \%$; nutrient agar, $42 \%$; autoclaved skim milk, $18 \%$ ) in Roux bottles for $3-5$ days at $30^{\circ} \mathrm{C}$. Enzymes to be used for developing the immuno-electrophoretic patterns (see later) were also produced in cultures on sterile skim milk without agar. The harvesting of cultures and the concentration and purification procedures have been described (Sandvik 1962).

Serums. Anti-proteinases were produced in rabbits. The concentrated enzyme preparations were mixed with equal amounts of Freund's complete adjuvant (Difco) (other lipid adjuvants were also used successfully) and injected subcutaneously in amounts of $2.0-4.0$ $\mathrm{ml}$ at 6-days' interval. Six to 8 days after the third injection the blood serums were tested for specific anti-enzymes. Serums were prepared against (a) Aeromonas salmonicida (ATCC 14174) and (b) Aeromonas proteolytica (ATCC 15338).

Caseinate medium. The indicator medium used to test for proteinase activity was prepared as follows: agar (Difco, Bacto-agar 0140-01), $1.40 \%$; sodium caseinate ${ }^{* *}$ ) (added as $4.0 \%$ solution of $\mathrm{pH} 6.2$ ), $1.00 \%$; thimerosal, $0.01 \% ; \mathrm{MgCl}_{2}$ (added as $\mathbf{1 0 . 0} \%$ solution), $0.004 \mathrm{M}$; in distilled water.

Serological differentiation. The antiserums were electrophorized by paper electrophoresis before being brought into contact with the enzymes. A type 3276, BN, LKB (Stockholm) apparatus was used with Schleicher and Schüll no. 2043 bmgl. paper and a $0.05 \mathrm{M}$ phosphate buffer, $\mathrm{pH} 6.2$ with thimerosal added to a final concentration of $1: 10,000$. The serums were applied in 8 to $10 \mu \mathrm{l}$ amounts and electrophorized at $120 \mathrm{v}$ for 16 to $18 \mathrm{hrs}$. The wet paper strips were then transferred immediately to the surface of the caseinate medium. After incubating at $37^{\circ} \mathrm{C}$ for 2 to $3 \mathrm{hrs}$., the strips were removed from the medium and replaced by narrow $(0.5$ to $0.8 \mathrm{~cm})$ strips of filter paper which had been immersed in solutions containing the proteinase to be tested. The enzyme solutions were preserved by adding thimerosal $(1: 10,000)$. Usually 3 to 4 filter paper strips were placed in parallel rows, within the $4 \mathrm{~cm}$ broad field of the electrophoresis paper for 2

*) NCIB $=$ National Collection of Industrial Bacteria, Torry Research Station, Aberdeen, Scotland.

**) P 914, Eastman Kodak, Rochester, N.Y., USA. 
to $18 \mathrm{hrs}$. at $37^{\circ} \mathrm{C}$, depending on the amount of development desired. Precipitation zones occurred along the enzyme-containing strips (Fig. 1). As shown in the previous report (Sandvik), the zones were interrupted at certain places by zones of no precipitation, as a result of inhibition of the proteolytic enzymes. The normal inhibitors in serum were localized in the $\alpha$ - and $\beta$-globulins on the anode side of the line of application, but the inhibition due to specific anti-enzymes occurred in the area of the $\gamma$-globulins. Under the present conditions the $\gamma$-globulins were situated on both sides of the line of application (Fig. 1). The width of the specific inhibition zone will depend on the concentration of anti-enzyme in the $\gamma$-globulins.

\section{RESULTS}

All the strains used in the study were strong producers of extracellular proteinases, which caused white zones of precipitation when applied into the caseinate medium. The anti-enzymes revealed typical specific zones of inhibition in the immuno-electrophoretic tests, when developed with the homologous enzyme solutions.

Proteinases produced by 10 additional strains of Aeromonas were also tested against the 2 anti-enzymes. The results are presented in Table 1.

Table 1. Proteinases produced by different Aeromonas species tested with anti-proteinases against Aeromonas salmonicida and Aeromonas proteolytica.

\begin{tabular}{lcc}
\hline & \multicolumn{2}{c}{$\begin{array}{c}\text { Reaction when testing the proteinases } \\
\text { with anti-enzymes against }\end{array}$} \\
\cline { 2 - 3 } Proteinases produced by & $\begin{array}{c}\text { Ae. salmonicida } \\
\text { (ATCC 14174) }\end{array}$ & $\begin{array}{c}\text { Ae. proteolytica } \\
\text { (ATCC 15338) }\end{array}$ \\
\hline $\begin{array}{l}\text { Ae. salmonicida (ATCC 14174) } \\
\text { Ae. salmonicida }\end{array}$ & +++ & - \\
6 Danish strains & +++ & - \\
Ae. salmonicida (NVH 2568) & +++ & - \\
Ae. liquefaciens (ATCC 14715) & A: +++ & - \\
Ae. punctata (ATCC 11163) & B: - & - \\
Ae. hydrophila (ATCC 9071) & B: +++ & - \\
Ae. proteolytica (ATCC 15338) & B: +++ & ++ \\
\hline
\end{tabular}

+++ : Inhibitory effect equal to homologous reaction.

$A$ and $B$ designate 2 different casein precipitating enzymes. 


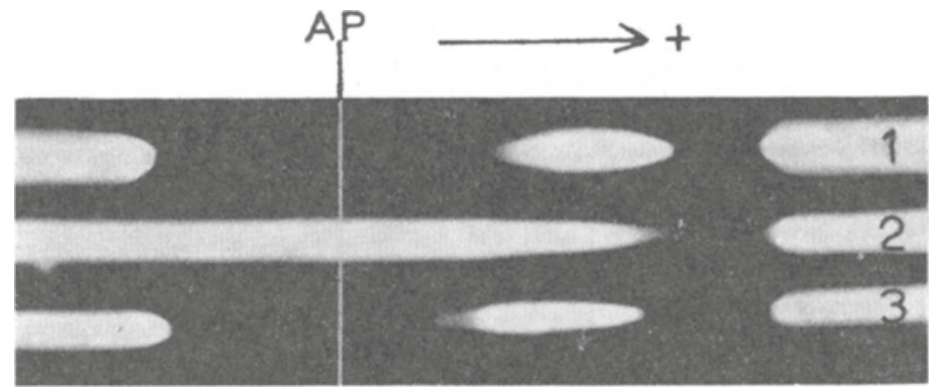

Figure 1. Electrophoretic patterns for antiserum against casein precipitating enzymes of Aeromonas salmonicida, transferred to sodium caseinate agar. Developments are performed with enzymes produced by 2 different strains of Ae. salmonicida (1 and 3) and Ae. proteolytica (2).

The specific antibodies are localized in a broad area on both sides of the line of application (AP) and the normal serum inhibitors to the right of this line. The electrophoresis was carried out in $0.05 \mathrm{M}$ phosphate buffer at $\mathrm{pH} 6.2$ for $18 \mathrm{hrs}$. at $120 \mathrm{v}$.

It can be seen that except for Ae. proteolytica, proteinases, produced in litmus milk cultures of all the other Aeromonas strains tested, reacted with the Ae. salmonicida anti-enzyme.

It was evident, however, that the group of organisms reacting with Ae. salmonicida anti-enzyme could be divided into 2 subgroups. The first one includes the $8 \mathrm{Ae}$. salmonicida strains, the proteinases of which were all completely inhibited by the specific antiserum (Fig. 1). In the other sub-group, including Ae. lique-

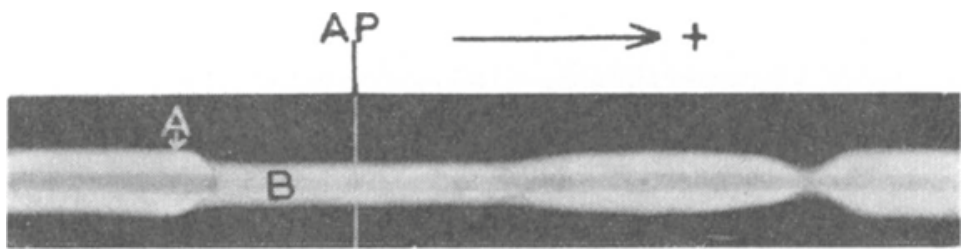

F i g u r e 2. Electrophoretic patterns for antiserum against the casein precipitating enzyme of Aeromonas salmonicida, transferred to sodium caseinate agar. Development is performed with enzymes produced by Aeromonas liquefaciens. "A" designates the periphery of the specifically inhibited enzyme fraction and " $B$ " the non-inhibited enzyme fraction in the $\gamma$-globulin area. The electrophoresis conditions as in Fig. 1. 
faciens (ATCC 14715), Ae. punctata (ATCC 11163) and Ae. hydrophila (ATCC 9071), characteristically 2 serologically different enzymes could be observed when crude litmus milk cultures were tested with Ae. salmonicida serum (Fig. 2). One of these enzymes (A-type) revealed a wide area of inhibition, while the other (B-type) was not inhibited at all. The latter enzyme produced a narrow uninterrupted precipitation line within the inhibition area of enzyme $\mathbf{A}$.

The only strain producing proteinases that reacted with the Ae. proteolytica anti-enzyme was the homologous strain (ATCC 15338).

The 2 anti-proteinases were also tested with proteinases produced in litmus milk cultures of other Gram-negative organisms, including Pseudomonas aeruginosa, Pseudomonas fluorescens, Aerobacter cloacae and Proteus vulgaris. All these tests were negative.

\section{DISCUSSION}

The investigations indicate that all the Aeromonas strains examined produce so-called casein precipitating enzymes (CPenzymes) (Sandvik 1962).

With the exception of the proposed new species Ae. proteolytica (ATCC 15338) close serological relationship seems to exist between the proteinases of the different species of the genus Aeromonas. Considering this fact as an important criterion of close taxonomic relationship between the said organisms (Liu 1962; Sandvik) it is still a question how many of the species should be retained within the genus Aeromonas. However, the present study does not reveal complete enzymo-serological identity between Ae. salmonicida on the one hand and Ae. liquefaciens, Ae. punctata and Ae. hydrophila on the other in as far as only 1 of at least 2 proteinases of the last-mentioned group was shared with Ae. salmonicida. It may therefore be taxonomically justifiable to consider Ae. salmonicida as a separate species or genetic variant different from the group including Ae. liquefaciens, Ae. punctata and Ae. hydrophila. Further, Ae. salmonicida is physiologically different from the latter group, for example as regards motility and several biochemical properties (Bergey's Manual 1957). Although the examined members of the liquefaciens - punctata - hydrophila group seem to be enzymo-serologically 
homogeneous, it may also be justifiable to subdivide the group into 2 species on the basis of biochemical properties according to Schubert (1967).

It is not surprising that the liquefaciens - punctata - hydrophila group of organisms produces 2 serologically different proteinases, since serologically and chromatografically different casein precipitating enzymes are also produced by one and the same strain of other organisms (Sandvik).

The experiments do not show any evidence of serological relationship between proteolytic enzymes of the genus Aeromonas and those of other Gram-negative organisms, including members of the genus Pseudomonas and the family Enterobacteriaceae. This observation supports the view that the aeromonads constitute a well defined genus, separated from other Gram-negative organisms. The enzymo-serological resemblance of Ae. salmonicida with the liquefaciens - punctata - hydrophila group also confirms the opinion that Ae. salmonicida taxonomically should be included in the genus Aeromonas, in spite of the non-motility of that species.

In conclusion, enzymo-serological investigation seems to be a convenient aid in the otherwise difficult detection of Ae. salmonicida and other members of the genus Aeromonas.

\section{REFERENCES}

Bergey's Manual of Determinative Bacteriology by R. S. Breed, E. G. D. Murray \& N. R. Smith. 7th Ed. The Williams \& Wilkins Company, Baltimore, Maryland 1957.

Caselitz, F. H. \& R. Günther: Hämolysinstudien mit Aeromonasstämmen. Zbl. Bakt., I. Abt. Orig. 1960, 180, 30-38.

Caselitz, F. H. \& D. Krebs: Serologische Studien mit Aeromonasstämmen. Tropenmed. Parasit. 1961, 12, 68-77.

Eddy, B. P.: Cephalotrichous, fermentative Gram-negative bacteria: The genus Aeromonas. J. appl. Bact. 1960, 23, 216-249.

Karlsson, K.-A.: Serologische Studien von Aeromonas salmonicida. Zbl. Bakt., I. Abt. Orig. 1964, 194, 73-80.

Liu, P. V.: Fermentation reactions of Pseudomonas caviae and its serological relationship to aeromonads. J. Bact. 1962, 83, 750753.

Merkel, J. R., E. D. Traganza, B. B. Mukherjee, T. B. Griffin \& J. M. Prescott: Proteolytic activity and general characteristics of a marine bacterium Aeromonas proteolytica Sp. N. J. Bact. 1964, 87, 1227-1233. 
Sandvik, O.: Studies on casein precipitating enzymes of aerobic and facultatively anaerobic bacteria. The Veterinary College of Norway, Oslo $1962,116 \mathrm{pp}$.

Schubert, R. H. W.: The taxonomy and nomenclature of the genus Aeromonas. Kluyver \& van Niel 1936. Part I. Suggestions on the taxonomy and nomenclature of the aerogenic Aeromonas species. Int. J. syst. Bact. 1967, 17, 23-37.

\section{SUMMARY}

A total of 12 strains of the genus Aeromonas were all good producers of so-called caseinate precipitating enzyme (CP-enzymes).

CP-enzymes produced by different Aeromonas species have been serologically compared. The technique is a special immuno-electrophoretic procedure, in which the proteolytic activity is neutralized by specific antiserums. No intergeneric cross-reactions could be demonstrated between enzymes produced by members of the genera Aeromonas, Pseudomonas, Proteus and Aerobacter. Interspecies cross-reactions occurred between enzymes of Aeromonas salmonicida and the species Ae. liquefaciens, Aa. punctata and Ae. hydrophila, whereas CPenzymes of Ae. proteolytica were not found to be serologically related to those of the other species of the genus. However, the liquefaciens - punctata - hydrophila group could be enzymo-serologically differentiated from Ae. salmonicida, because that group in addition to the common enzyme fraction also possesses a fraction not found in Ae. salmonicida.

The enzymo-serological procedure has been found a convenient tool in the identification of Ae. salmonicida and other aeromonads.

\section{ZUSAMMENFASSUNG}

Serologische Untersuchungen von Proteinasen produziert von Aeromonas salmonicida und anderen Aeromonaden.

Sämtliche von insgesamt 12 Stämmen des Genus Aeromonas produzierten reichliche Mengen der sogenannten Kaseinat-präzipitierenden Enzyme (CP-Enzyme).

CP-Enzyme, die von verschiedenen Aeromonas-Stämmen produziert worden waren, wurden serologisch verglichen. Die Technik ist eine spezielle immunoelektrophoretische Methode, bei welcher die proteolytische Aktivität von spezifischen Antiseren neutralisiert wird. Es konnten keine intergenerischen Kreuzreaktionen zwischen den Enzymen, die von Stämmen der Gattungen Aeromonas, Pseudomonas, Proteus und Aerobacter produziert worden waren, festgestellt werden. Artenweise Kreuzreaktionen kamen zwischen den Enzymen von Aeromonas salmonicida und den Arten Ae. liquefaciens, Ae. punctata und Ae. hydrophila vor. Dagegen zeigte es sich, dass CP-Enzyme von Ae. proteolytica produziert nicht mit Enzymen von anderen Arten innerhalb dieser Gattung produziert serologisch verwandt waren. Die Lique- 
faciens - Punctata - Hydrophilagruppe liess sich jedoch von Ae. salmonicida mit Hilfe von der enzymo-serologischen Methode unterscheiden, weil diese Gruppe ausser der gemeinsamen Enzymfraktion noch eine Fraktion produzierte, die bei Ae. salmonicida nicht vorkam.

Es wurde festgestellt, dass die enzymo-serologische Methode ein geeignetes Hilfsmittel bei der Identifizierung von Ae. salmonicida und anderen Aeromonaden ist.

\section{SAMMENDRAG}

Serologiske studier over proteinaser produsert av Aeromonas salmonicida og andre aeromonader.

Samtlige av ialt 12 stammer av genus Aeromonas produserte rikelige mengder av såkalte kaseinat-presipiterende enzymer (CP-enzymer).

CP-enzymer produsert av forskjellige stammer av Aeromonas er blitt sammenliknet serologisk. Teknikken er en spesiell immunoelektroforetisk metode hvorved den proteolytiske aktivitet blir n $\varnothing$ ytralisert av spesifikke antisera. Det kunne ikke påvises intergeneriske kryssreaksjoner mellom enzymer produsert av representanter for slektene Aeromonas, Pseudomonas, Proteus og Aerobacter. Artsvise kryssreaksjoner forekom mellom enzymer fra Aeromonas salmonicida og artene Ae. liquefaciens, Ae. punctata og Ae. hydrophila, mens CP-enzymer produsert av Ae. proteolytica ikke ble funnet å være serologisk beslektet med enzymer produsert av andre arter $\mathrm{i}$ dette genus. Liquefaciens - punctata - hydrophilagruppen kunne imidlertid atskilles fra Ae. salmonicida ved hjelp av den enzymo-serologiske metode, fordi denne gruppen i tillegg til den felles enzymfraksjon også produserte en fraksjon som ikke forekom hos Ae. salmonicida.

Den enzymoserologiske metode ble funnet å være et egnet hjelpemiddel ved identifisering av Ae. salmonicida og andre aeromonader.

(Received October 18, 1967). 